\title{
2
}

\section{Will China fall into stagflation?}

\author{
Yiping Huang
}

\section{The new policy challenge}

The growing risk of stagflation has perhaps been one of the most important macroeconomic surprises around the world since the beginning of the year. China is not excluded from the risk. According to the National Bureau of Statistics (NBS), real gross domestic product (GDP) growth moderated from 11.9 per cent in the fourth quarter of 2007 to 10.6 per cent in the first quarter of 2008. Between mid 2006 and late 2007, the growth of export volumes fluctuated largely within the 20-30 per cent range. After that, however, export growth tanked (Figure 2.1). The growth of industrial production showed a similar trend, especially when adjustments were made for changed producer prices.

Meanwhile, inflation rates continued to reach new highs. During much of 2005 and 2006, the headline consumer price index (CPI) stayed well below 2 per cent. From the beginning of 2007, however, it began to rise steadily (Figure 2.2). In February 2008, the CPI reached a new 11-year high of 8.7 per cent. Rising inflation was a result initially of spikes in pork prices, but soon it spread to other food markets, with the overall food CPI exceeding the 20 per cent level in early 2008. The non-food CPI has been largely stable so far; however, nonfood CPI could be underestimated as the government controls domestic fuel prices. Producer prices accelerated to 8.2 per cent in May 2008 from below 3 per cent a year ago. 
Figure 2.1 Growth of volumes of Chinese exports and imports, January 2005-May 2008 (per cent per year/year)

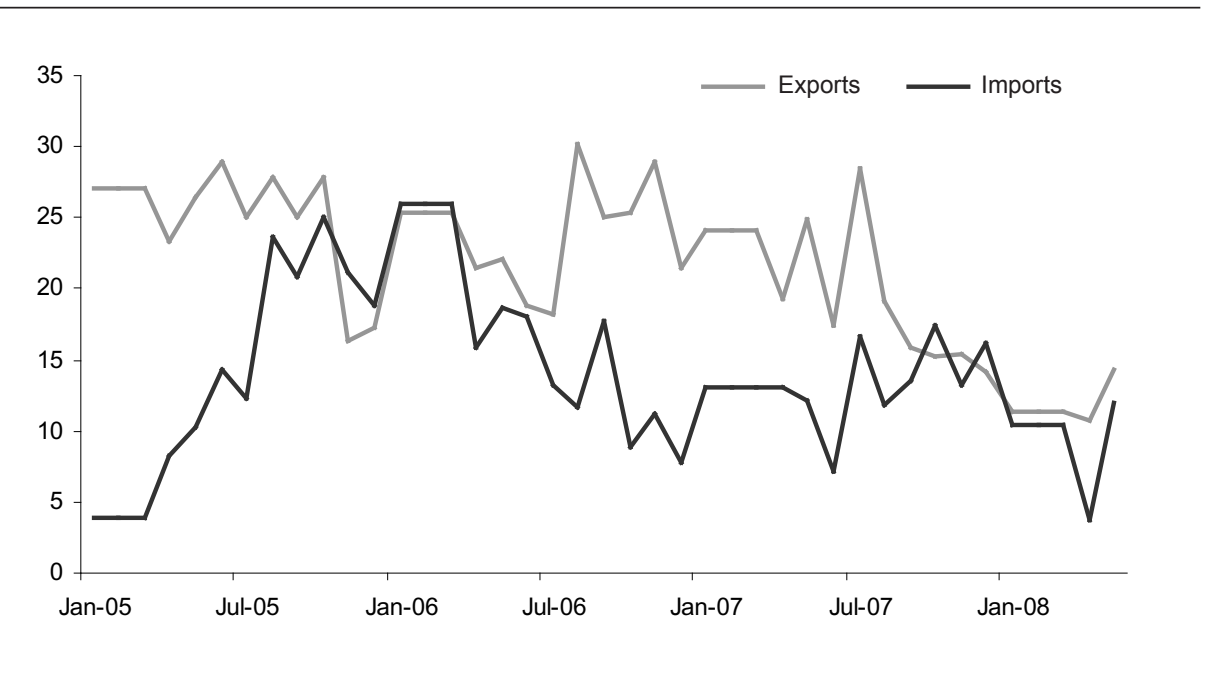

Note: In drawing the chart, I have averaged year-on-year growth rates for January, February and March and smoothed out the effect of the Chinese New Year holiday.

Sources: CEIC Data Company and Citi.

\section{Figure 2.2 China's headline CPI, food CPI and non-food CPI,} January 1999-May 2008 (per cent per year/year)

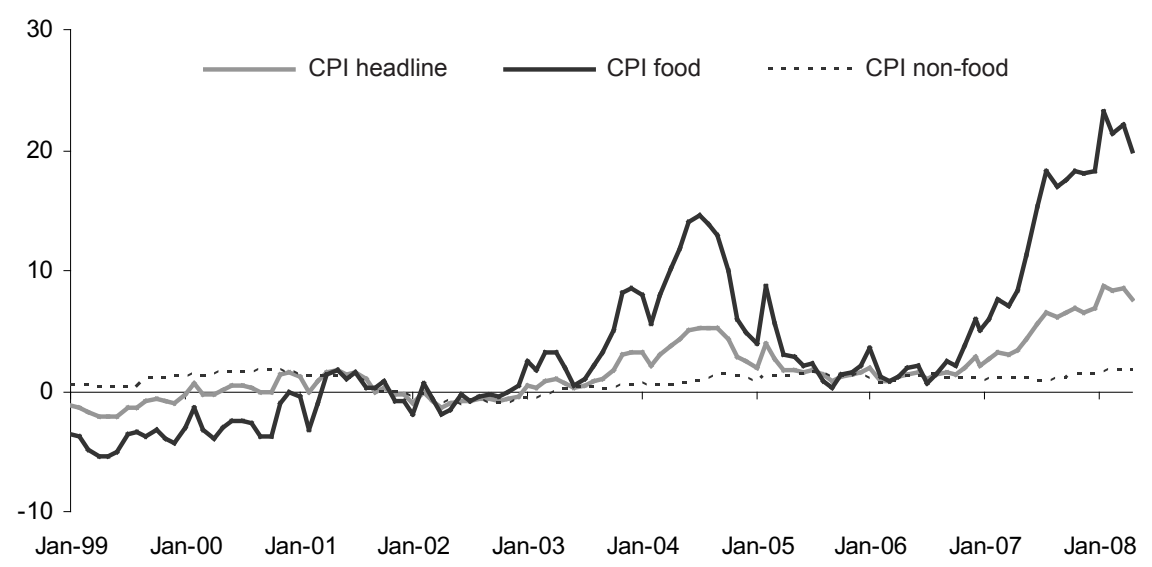

Sources: CEIC Data Company and Citi. 
The combination of slowing growth and rising inflation poses serious challenges for Chinese macroeconomic policymaking. Deterioration of the US economy, the continuing surge of oil prices, liberalisation of domestic factor markets, the upcoming Olympic Games and unexpected events such as the recent snowstorm and earthquake further complicate policymakers' decisions.

In fact, the Chinese government's macroeconomic policy stance has already swung notably during the past months. At the beginning of December 2007, the Central Economic Work Conference identified two top policy priorities for 2008: fighting overheating and controlling inflation. As the economic conditions in the United States deteriorated sharply in early 2008, however, the State Council added an additional goal for its macroeconomic policies: preventing a slide of the economy. From May 2008, the environment shifted again. The near-term outlook for the United States improved steadily, with many investors believing that the worst might be over. In the meantime, inflation rates continued to ratchet up. The Chinese authorities again toughened their stance for battling inflation problems.

The heated policy debate has not ended. The 'hawks' advocate aggressive policy tightening, including sharp appreciation of the currency. They argue that inflation, regardless of its composition, is a monetary phenomenon; therefore, only aggressive monetary tightening can tame inflation. The 'doves', on the other hand, warn about the downside risks to the economy and call for some tolerance of higher inflation. They point, in particular, to already declining corporate profits and collapsed equity prices. It follows, then, that continuous aggressive tightening will not only kill the growth engine, it could escalate social and financial risks.

In this chapter, I argue that the scenario of stagflation is unlikely to materialise in China any time soon. Development in three areas could, however, reinforce the challenge of slowing growth and rising inflation in the coming year: deceleration of the US economy, elevated international oil prices and gradual cost normalisation in China. We are likely to see growth shifting to a slightly slower gear-about 10 per cent-while inflation will ratchet up to higher levels, of about 5-7 per cent, in the coming year or two.

In this environment, policy decisions will likely continue to be difficult. With elevated inflation pressure, however, the central bank will probably maintain its tightening bias, with a focus on direct liquidity management. Steady appreciation of the renminbi should also continue. In the meantime, fiscal policy could turn more expansionary to support post-disaster reconstruction and to facilitate industrial upgrading. If an expansionary fiscal policy successfully boosts domestic demand and reduces the external surplus, it could in the end help ease pressures on the currency and inflation. 


\section{US growth and the decoupling thesis}

Since the outbreak of the sub-prime crisis, US economic activity has slowed steadily. The annualised quarter-on-quarter real GDP growth rate fell from close to 5 per cent during the third quarter of 2007 to below 1 per cent in the next two quarters. Economists are still divided about whether the US economy will fall into deep recession, but most agree that US economic growth is likely to stay well below the trend level for at least several quarters. This should have important implications for the outlook for the Chinese economy in the coming year.

To some economists, slowing growth in the United States but steady expansion of the Chinese economy in 2007 provided convincing evidence of the decoupling thesis. The decoupling proposition suggests that as Asian economies grow and economic interactions between them deepen, the relative importance of the US economy for Asia will decline.

The decoupling thesis is an exaggeration of real economic relations, to say the least. If anything, Asia and China's economic linkages with the United States strengthened, rather than weakened, during the past 10 years. China, in particular, became a much more open economy. The export share of GDP rose from 18.6 per cent in 1997 to 36.1 per cent in 2007, while the share of United States-bound GDP increased from 3.3 per cent to 6.9 per cent in the same period (Figure 2.3).

The fact that Chinese growth did not soften alongside slowing US growth in 2007 was probably more of a special situation than a general rule. First, the slow-down in the United States in 2007 was concentrated in the housing sector; non-housing activities continued to grow at 2.5 per cent. The situation has now changed and the growth slow-down in the United States in 2008 is occurring mainly in the non-housing sector, especially in consumer spending and business investment. Second, softening of United States-bound exports was offset by European Union-bound exports, when the euro strengthened significantly. This will, however, be difficult to repeat; the European economy already shows increasing weakness and the euro is under pressure to weaken, at least in the coming quarters.

It is probably also premature to count on growing intra-regional trade to support Asian economic growth. Although intra-regional trade grew exponentially after China joined the World Trade Organization (WTO) in 2001, the majority of this-at least 70 per cent-was trade in intermediate goods. The key destinations for Asia's finished-goods exports are the G3 economies (the United States, the European Union and Japan, 61 per cent), Asia (21 per cent) and the rest of the world (18 per cent). This implies that Asian domestic 
Figure 2.3 Shares of total exports and United States-bound exports in China's GDP, 1993-2007 (per cent)

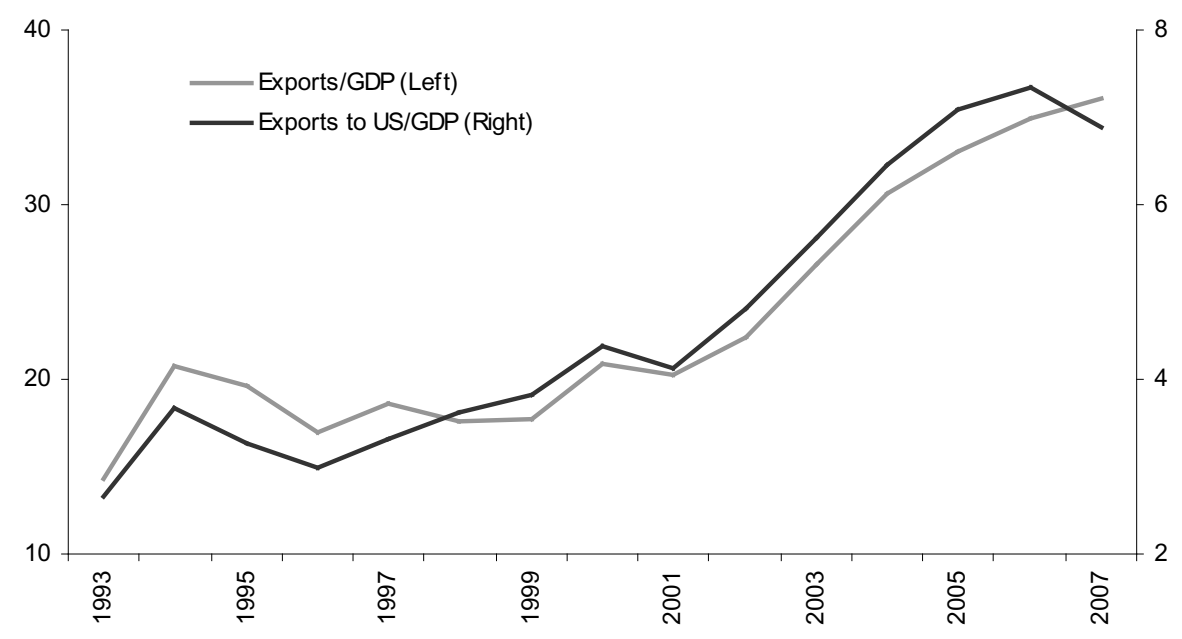

Sources: CEIC Data Company and Citi.

demand is still not significant enough to support regional economic growth, should the US economy slow sharply. Asia and China could become decoupled from the United States and other industrial economies when regional domestic demand is large enough, but that is at least 10 years away.

I examine the likely impacts of a US slow-down on Asian economies through model simulations applying the Oxford Economic Forecasting (OEF) model. The results suggest that a 1 percentage-point slow-down in the US economy could lower Asian economic growth on average by 1.1 percentage points and reduce Chinese growth by 1.3 percentage points (Figure 2.4). The real changes are likely to be smaller as the model cannot endogenously generate a policy response to support growth. In China, for instance, the government will most likely employ fiscal stimuli if external demand weakens significantly.

Another mechanism that could offset growth moderation in China is the likely change in capital flows. In a world faced with slowing US growth and rising US financial risk, capital inflows to China could accelerate, as evidenced by changes during the first two quarters of 2008. Unfortunately, however, China's economic constraint is not a lack of capital; rather, too much capital inflow could further increase domestic liquidity and therefore add further pressure to domestic inflation. 
Figure 2.4 Model simulation: impacts of a 1 per cent slow-down of the US economy (per cent)

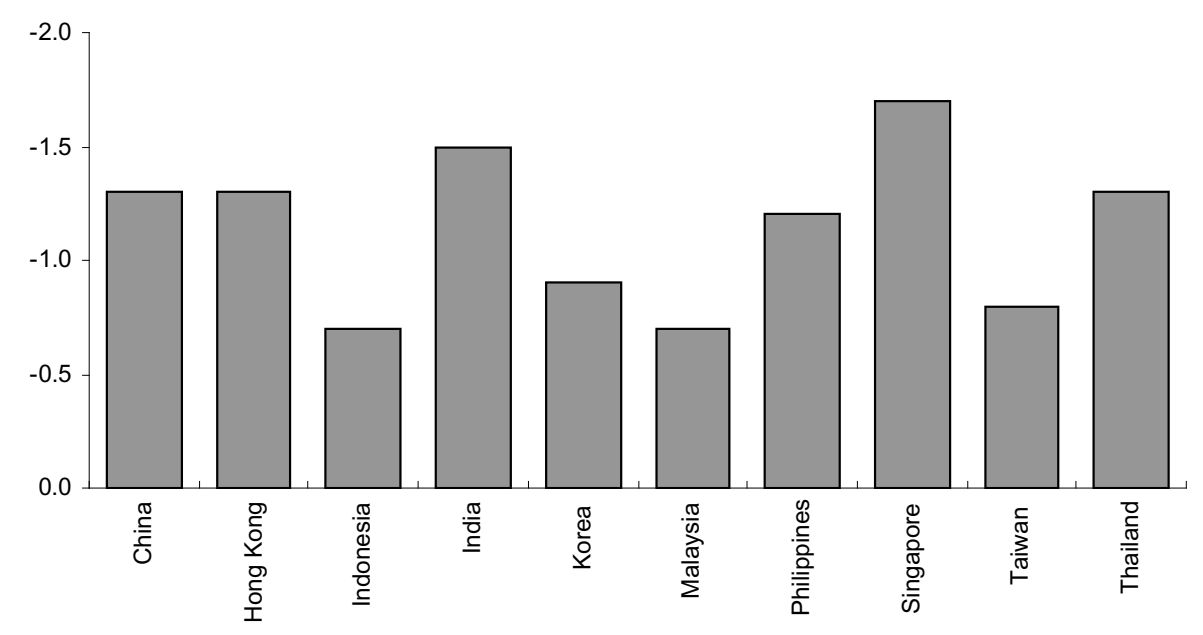

Source: Simulation results applying the Oxford Economic Forecasting model.

Figure 2.5 Nominal and real oil prices, January 1959 - June 2008 (US\$/barrel)

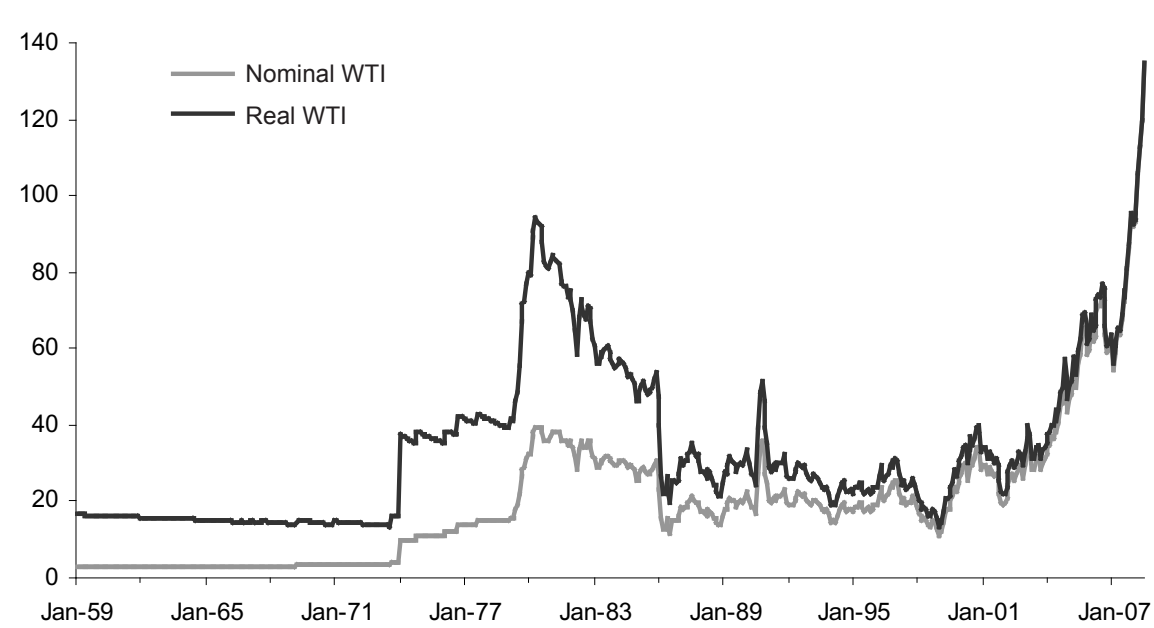

Source: Citi. 


\section{The new oil price shock}

One of the biggest macroeconomic surprises during the past year was the combination of moderating global economic growth and rising oil prices. The West Texas Intermediate (WTI) oil price rose from less than US\$67.50 per barrel in June 2007 to US $\$ 135 /$ barrel in June 2008 (Figure 2.5). Even in real terms, the current WTI price already exceeded the previous peak during the 1980 oil crisis.

There are a number of hypotheses for why oil prices increased rapidly although the global economy showed softness. The first hypothesis highlights the growing importance of the emerging market economies in international oil markets. In 2008, for instance, the emerging market economies are likely to account for all net increases in global oil demand. The second hypothesis points to rising marginal costs of oil production. As it becomes more costly to produce oil, prices have to go up regardless of the conditions of demand. A third hypothesis reveals a new contribution from financial investment demand, compared with real economic demand, in an environment with a depreciating US dollar. Financial investment usually accounted for about 16 per cent of global oil demand; today, this share is already 60 per cent.

The first two hypotheses explain why oil prices have been on a long-term upward trend, but they fail to account for the doubling of oil prices during the past year. The third hypothesis-that is, financial demand outweighing physical demand-probably plays a dominant role in the latest episode of oil price increases. If that is the case, however, oil prices could correct in the coming year, especially if the US dollar rebounds steadily. Even if corrections do happen, prices could stay at elevated levels. The good old days of oil prices of $\$ 20 /$ barrel are probably long gone. Oil prices averaged $\$ 72 /$ barrel in 2007 and $\$ 110 /$ barrel during the first six months of 2008.

High oil prices could have significant impacts on the Chinese economy. According to simulation results applying the OEF model, a $\$ 10 /$ barrel increase in the oil price could lower China's real GDP growth by 0.4 percentage points and lift its CPI by 0.2 percentage points. The real observed effects, especially the growth effect, were, however, smaller than the model's predictions.

One important reason for the smaller than predicted oil price impacts is the declining share of oil in production over time. Falling oil intensity of GDP is a global trend as technologies improve. In China, efficiency gain through reform efforts further reinforces this trend. During the 30 years of economic reform, China's oil intensity improved by about 70 per cent (Figure 2.6). As a result, current oil expenditure's share of nominal GDP is still significantly lower than the peak in 1980, despite the recent surge in oil prices. This means that GDP 
growth elasticity of oil prices changes over time, while model predictions are based on historical correlations.

Another important reason for the smaller than expected oil price impacts is the domestic fuel price subsidy; therefore, changes in international oil prices do not necessarily affect domestic prices for end users. This effectively lessens impacts on GDP and inflation. The domestic economy is not, however, entirely insulated. Oil and electricity shortages are a common and growing phenomenon. In 2007, when international oil prices averaged US $\$ 72 /$ barrel, China's fiscal subsidy to oil prices was about US $\$ 8.2$ billion, or equivalent to 0.2 per cent of that year's GDP. The uncompensated losses of oil refiners could be even greater.

China is not the only economy in Asia that subsidises domestic fuel prices. In India, Indonesia and Malaysia, fiscal subsidy to oil prices accounted for 1-1.5 per cent of GDP in 2007. All these countries adjusted domestic prices in May or June in order to reduce the fiscal burden and to improve energy efficiency. The rising oil prices already generated serious consequences for the Chinese economy. Fiscal burdens grew significantly. If oil prices are sustained at the

\section{Figure 2.6 Share of oil expenditure in GDP and oil intensity of GDP,} 1976-2007

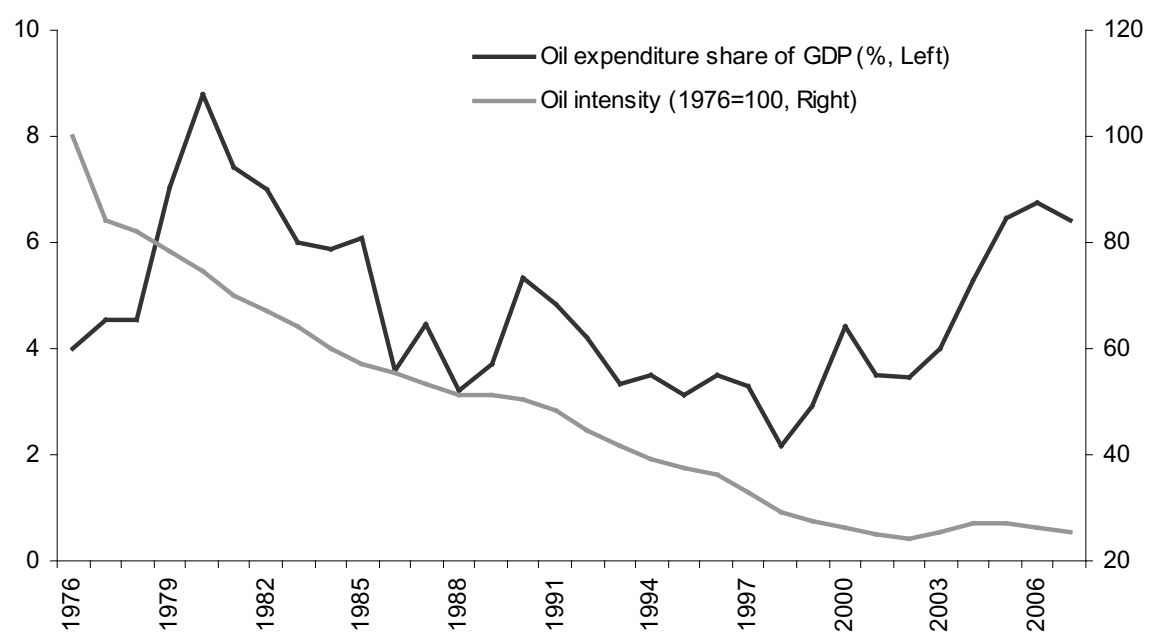

Source: Citi. 
US $\$ 130 /$ barrel level, the explicit and implicit subsidies could amount to 1-2 per cent of GDP. The government is, however, already stretching its expenditure on disaster relief and reconstruction. More importantly, price controls also cause serious inefficiency problems and distortions to economic structure. Lower energy costs already attract lots of energy-intensive industries to China, such as steel mills and aluminium smelters-industries in which China does not have a comparative advantage. China is therefore really subsidising the global industry. Lack of demand response in China, in turn, added further pressures to international oil markets, especially as China was already a key player. Between 2003 and 2007, China accounted for about one-third of the net increase in global oil demand.

In mid June, the government finally announced to lift gasoline prices by 16.8 per cent, diesel prices by 18.1 per cent and electricity tariff by 4.5 per cent. The upward adjustment of domestic fuel prices will probably add 0.3 percentage point to inflation in the coming months.

These moves were relatively modest compared with the doubling of the international prices during the past months. In particular, as the policy change does not establish new mechanism linking domestic prices to international prices, distortions remain and likely will grow again if international oil prices continue to rise. But they were important first steps in reducing domestic distortions. It's possible that the authorities may adjust domestic oil prices in the coming year.

\section{The process of cost normalisation}

Fuel price increases are only a small part of the broad cost adjustment currently under way in China. The average wage, for instance, has been growing at close to 20 per cent year on year during the past year (Figure 2.7). Average land prices also rose by more than 15 per cent. The base lending rate is at 7.47 per cent-nearly 1 percentage point higher than a year ago. The real average bank lending rate is already above 9 per cent. Many companies are already feeling the rising cost pressures and some have been forced to close.

Cost distortion has been one important feature of Chinese economic institutions during the reform period. After 1978, the authorities proceeded to rapidly liberalise the goods market. The factor markets, however, remain highly distorted. For instance, policies on labour mobility are still highly restrictive. Land belongs to the public and the government controls its allocation. Stateowned entities dominate the allocation of capital. In other words, there are not yet well-developed free markets for production factors. As a result, prices for labour, capital and land are still significantly depressed. According to my rough 


\section{Figure 2.7 Growth of land prices and average wages in China,} 2001-2008 (per cent per year/year)

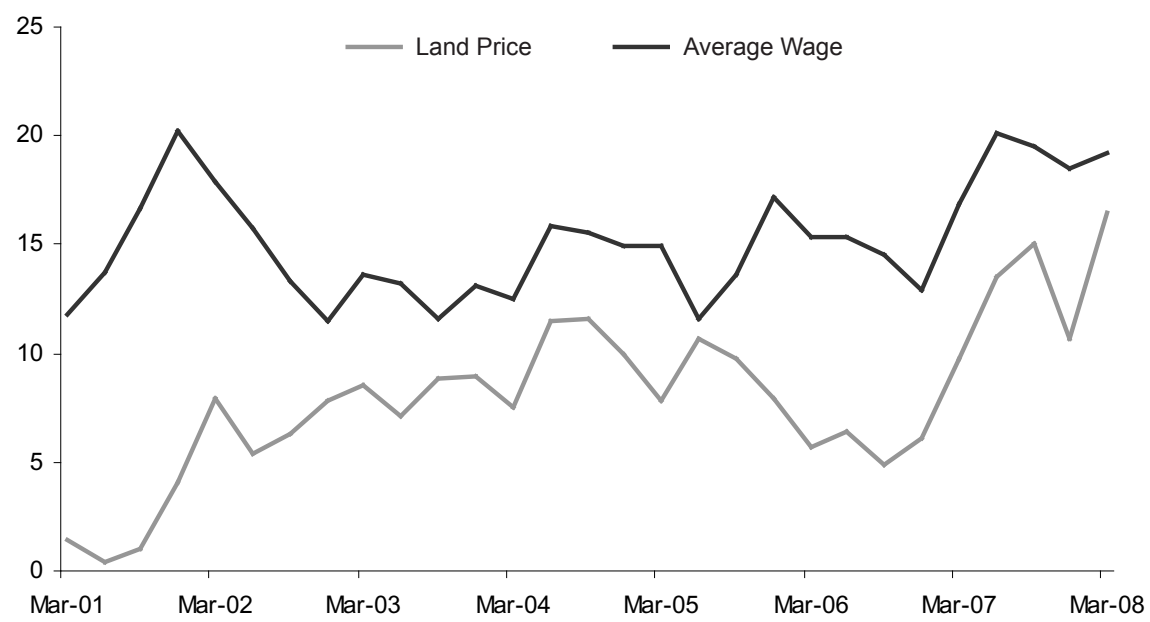

Sources: CEIC Data Company and Citi.

\section{Table 2.1 Estimation of China's cost distortion (RMB billion)}

\begin{tabular}{|c|c|c|}
\hline Item & Cost & Key assumption \\
\hline 1. Labour & 203 & Assuming the new labour law is fully enforced \\
\hline 2. Land & 154 & Assuming 20 per cent of land sales revenue in 2006 \\
\hline 3. Energy & 1,632 & $\begin{array}{l}\text { RMB1,572 billion price difference; RMB } 60 \text { billion in } \\
\text { resource taxes }\end{array}$ \\
\hline 4. Capital & 337 & $\begin{array}{l}\text { Assuming a } 2 \text { percentage-point hike in policy rates after } \\
\text { financial liberalisation }\end{array}$ \\
\hline 5. Environment & 1,080 & $\begin{array}{l}\text { Without considering the RMB287.4 billion per annum } \\
\text { maintenance fee }\end{array}$ \\
\hline 6. Others & 429 & Equivalent to the amount of export tax rebates in 2006 \\
\hline Total & 3,835 & 15.5 per cent of 2007 GDP \\
\hline
\end{tabular}

Source: Citi. 
estimation, cost distortions probably totalled RMB3,835 billion in 2007—or 15.5 per cent of GDP (Table 2.1).

While cost distortions were not all the result of deliberate policy decisions, they were consistent with the policymakers' clear objective of promoting production and economic growth. By depressing opportunity costs for most factors, distortions in factor markets reduce production costs and ensure high profits in production. This supports continuation of unusual investment growth. Distortions in factor markets, therefore, are like subsidies to producers and investors, which fuel extraordinary growth of the Chinese economy.

The broad production subsidy regime also caused a few problems and risks. First, economic growth becomes increasingly investment dependent because of high profits from production and strong incentives for investment. Second, depressed production costs boost exports and attract foreign direct investment. Third, income distribution deteriorates quickly. Owners of enterprises capture vast production profits. In fact, these have developed into serious risks in China, threatening the sustainability of its rapid growth. This suggests that such a regime of cost distortion cannot continue forever.

In fact, important changes have already begun to take place. The recently introduced Labour Contract Law provides better protection of workers' rights, including their job security and social welfare benefits. Labour costs could rise sharply once the new law is rigorously implemented. Energy prices are still controlled by the State, but the government now intends to grant greater roles for the market mechanisms. Capital costs have also started to rise, as a result of the tightening of domestic liquidity and appreciation of the currency. Finally, the authorities have stepped up efforts to protect the environment, responding to the recent sharp deterioration of water, land and air quality.

This is what I describe as cost normalisation. The whole process could take decades to complete, but rises in production costs could again add pressure to growth and inflation.

\section{Policy considerations}

Policy outlooks could be very uncertain in an economic environment in which growth slows but inflation rises. Policymakers might become more hawkish when inflation becomes a prominent risk but might turn more dovish when there is significant pressure on growth. We need to have a good understanding of several critical questions in order to gauge the likely policy trend in the coming year.

First, is China's inflation a temporary price adjustment or more structural in nature? Policy actions should be more restrained if it's the former but can be more aggressive if it's the latter. The official documents so far still use the 
phrase 'structural price increases'. I am sympathetic to the view that this round of inflation was triggered initially by food prices, but almost every major episode of high inflation during the reform period began with rising food prices. With loose monetary conditions, the effects of increases in food prices could spread quickly to other sectors. Tightening of monetary policy should therefore continue in order to control inflation.

Second, is the Chinese economy overheating? Many economists attribute rising inflation to such a problem. Real GDP growth averaged more than 10 per cent during the past five years and reached 11.9 per cent in 2007. High growth does not, however, necessarily equate with overheating. Overheating occurs only when the economy grows at a pace faster than domestic resources can support. China recorded current account surpluses for 14 consecutive years. In 2007, the current account surplus reached 10.8 per cent of GDP. This means that China saved domestic resources for investment overseas; therefore, China's inflation risk probably stems mainly from the liquidity condition instead of the overheating problem.

Third, will the US slow-down drag down the Chinese economy significantly? In the case of a deep and protracted US recession, China's exports could suffer badly. This might not only slow economic growth, it could create serious overcapacity problems in China, which would, in turn, ease China's inflationary pressure. Although the US economy still faces significant uncertainty, its nearterm outlook has improved compared with two months ago. This should help limit the downside risks for the Chinese economy.

Finally, will the Olympic Games be an obstacle to the tightening policy? Economists have come to agree that the boom and bust cycle associated with the Olympic Games, often observed in many countries, might not materialise in China. The games could, however, still serve as an important psychological factor for investors and policymakers. While it is unlikely to stop the tightening policies if inflation remains a major macroeconomic risk, policymakers will probably be cautious in determining the timing of such policies. Decisive policies are therefore more likely to be implemented after the games than before them.

China began its current round of tightening policy in early 2007, when the People's Bank of China (PBC) first raised its base policy rates by 27 basis points. In subsequent months, the PBC hiked its policy rates another five times (Figure 2.8). Meanwhile, the central bank also adopted a series of measures to directly manage the liquidity conditions, including reserve requirements, open market operations and credit control.

The focus of the tightening policies probably shifted recently. The PBC has not hiked its policy rate since the beginning of 2008; it has, however, stepped up efforts to control liquidity. By the end of June 2008, the commercial banks' 
reserve requirement had reached 17.5 per cent. Direct credit control also began to affect commercial banks' loan growth (Figure 2.9). According to the PBC, the real average lending rate rose to more than 9 per cent in the second quarter of 2008, compared with about 8 per cent at the end of the year and the base lending rate of 7.47 per cent.

The effects of the tightening measures on broad liquidity conditions have been less than clear. The simple excess liquidity indicator-subtracting the growth of industrial production from the growth of broad money (M2) - suggests that the liquidity conditions probably loosened again from the beginning of 2008 (Figure 2.9). This probably confirms that the central bank is still lagging behind the market. More importantly, it likely reflects the burdens created by massive capital inflows.

Unfortunately, no one can satisfactorily explain the nature and composition of capital inflows. Between January and April 2008, foreign exchange reserves rose by US $\$ 228$ billion, while the sum of the trade surplus and utilised foreign direct investment explained only US $\$ 93$ billion (Figure 2.10). Some economists attribute the gap between the two to 'hot money'. Hot money is, however, probably not the proper term to describe recent increases in capital inflow,

Figure 2.8 Central bank benchmark lending rate and commercial bank base lending rate, January 1991-May 2008 (per cent)

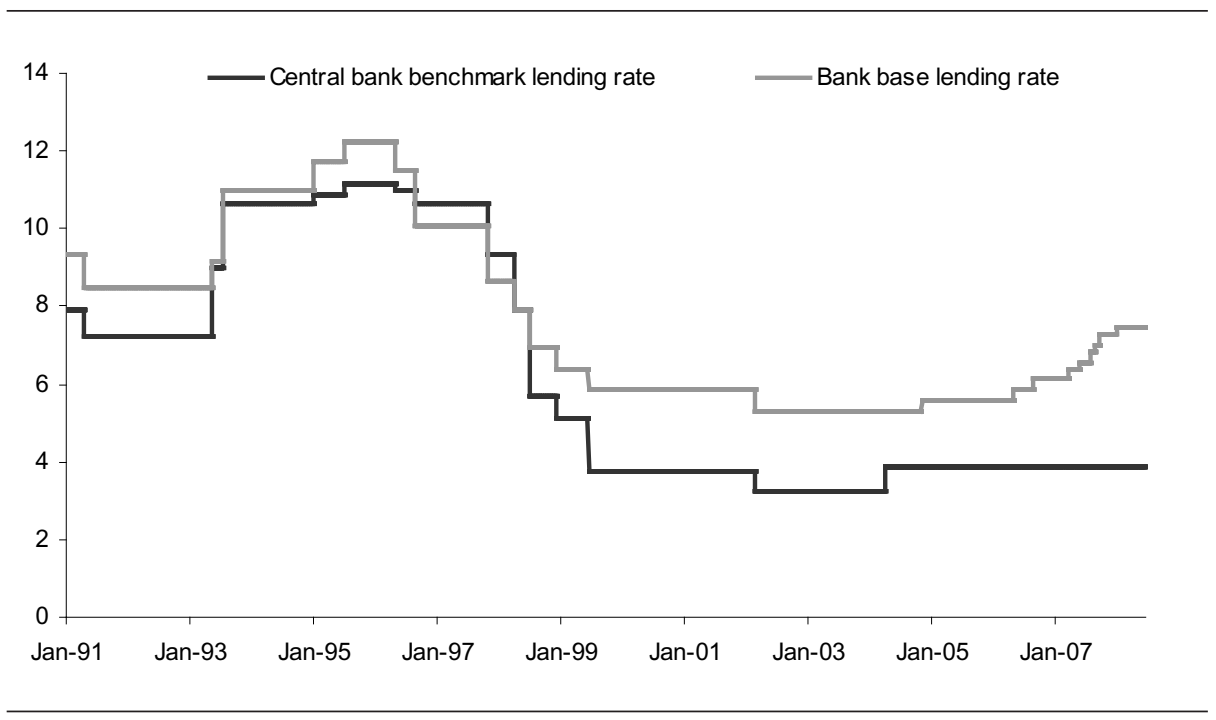

Sources: CEIC Data Company and Citi. 
Figure 2.9 Excess liquidity and bank credit, January 1998-May 2008 (per cent per year/year)

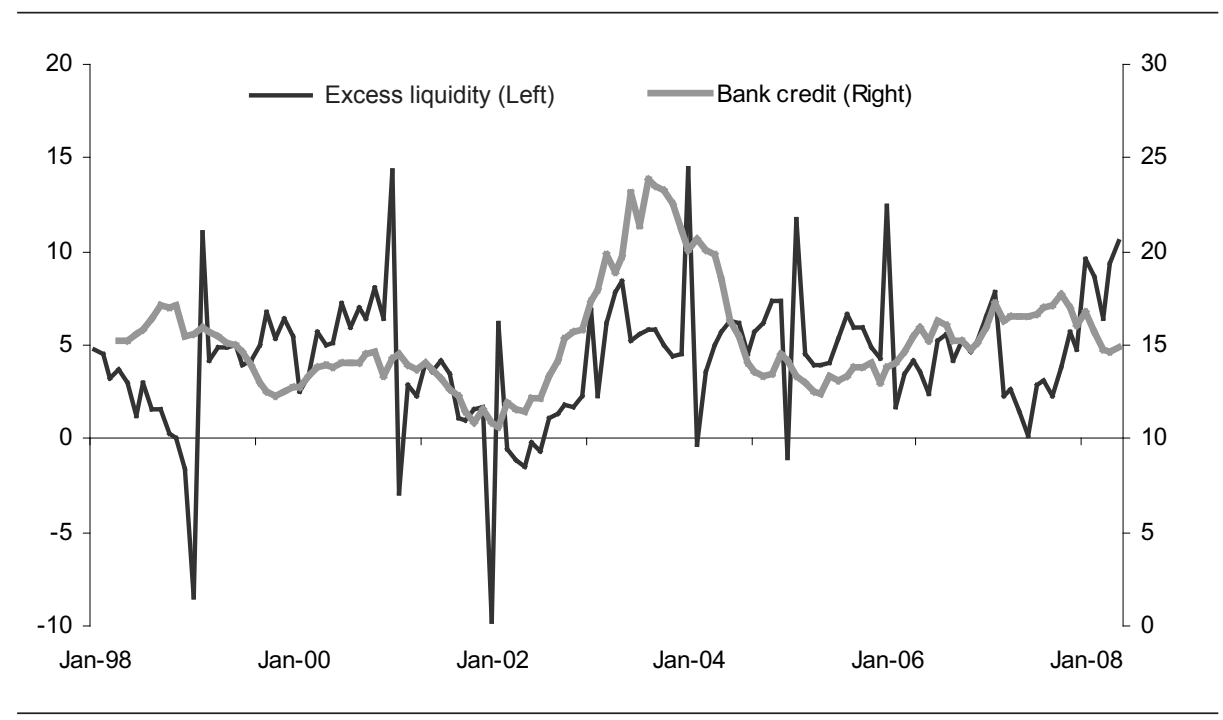

Sources: CEIC Data Company and Citi.

Figure 2.10 Monthly increase in foreign reserves, the trade surplus and utilised foreign direct investment, January 2007-May 2008 (US\$ billion)

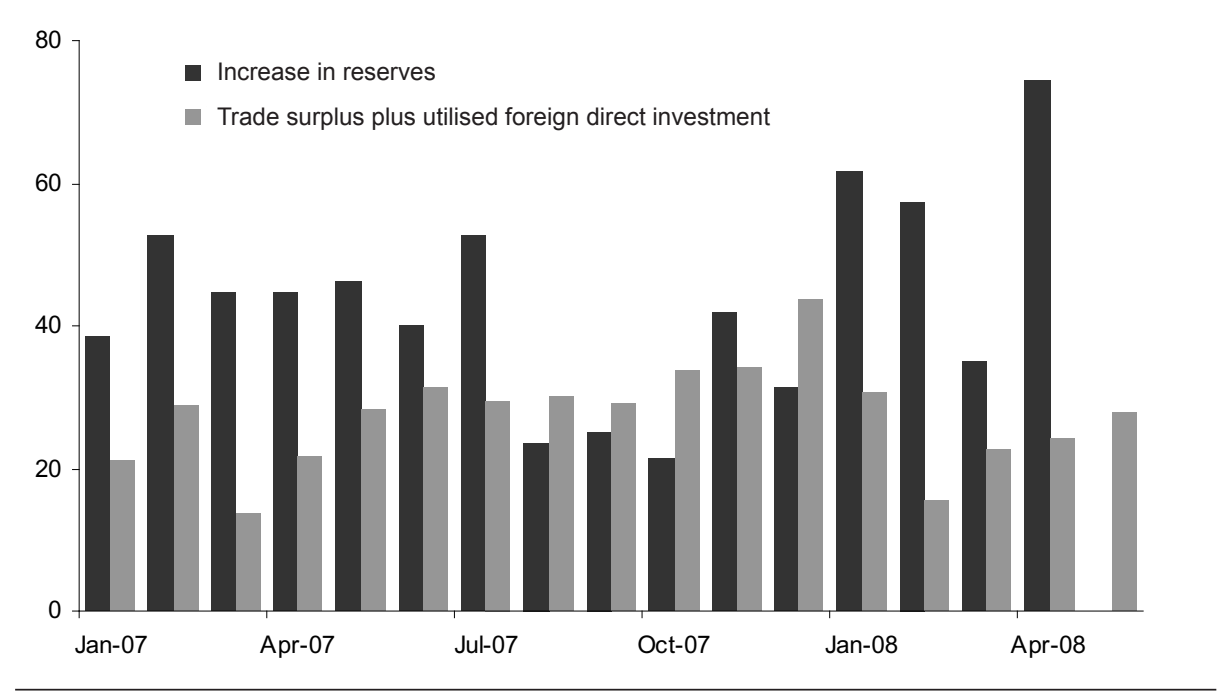

Sources: CEIC Data Company and Citi. 
Figure 2.11 The renminbi's nominal effective exchange rate and bilateral exchange rate against the US dollar, October 2006-June 2008

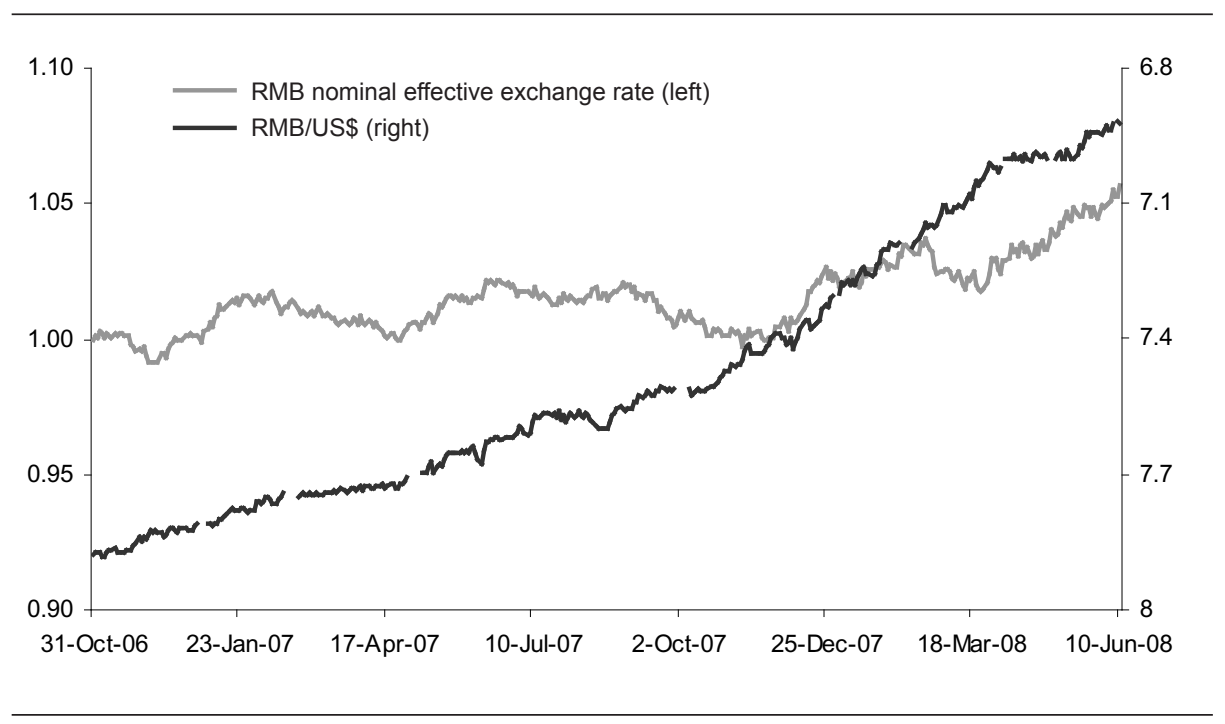

Sources: CEIC Data Company and Citi.

Figure 2.12 Shanghai A share stock-market: PE ratio and index, January 2001 - May 2008

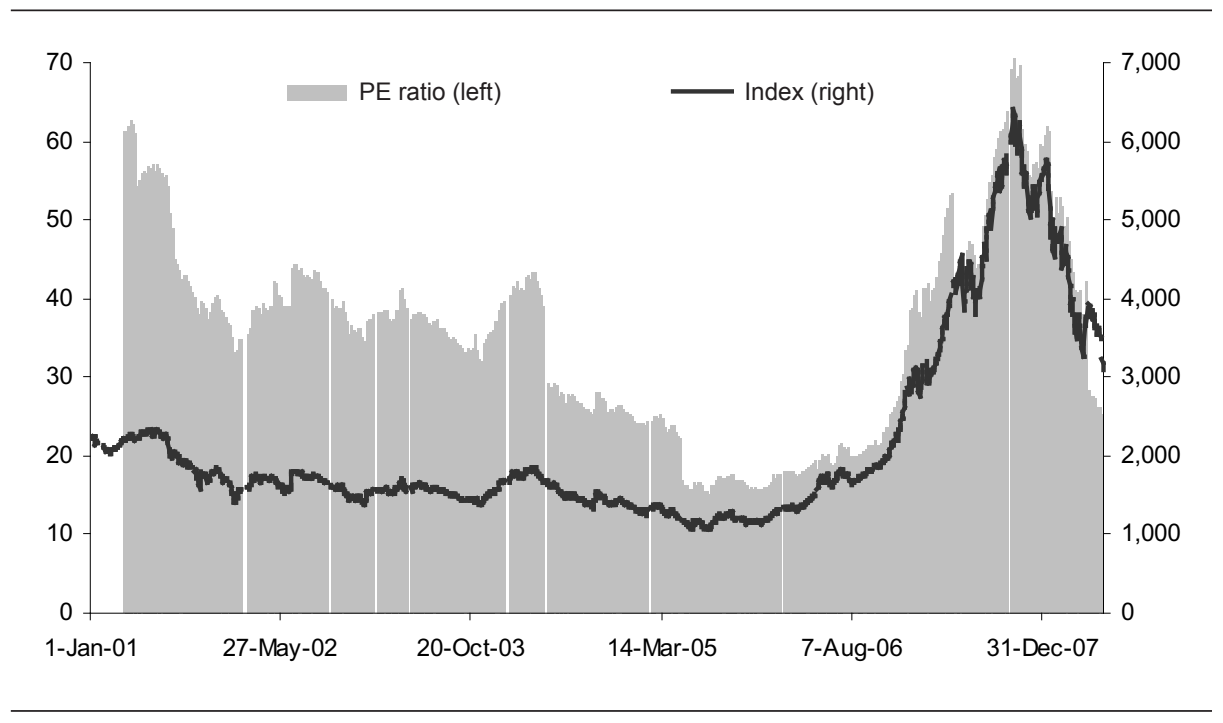

Sources: CEIC Data Company and Citi. 
as much of it will likely stay within China for relatively long periods. There is, however, no denying that capital inflows surged in recent months.

There were probably many reasons why capital inflows increased dramatically during the past months. One reason could be the financial crisis in the United States. In a volatile international capital market, China becomes a safe heaven. Another reason might be the rapid appreciation of the renminbi, which encouraged expectations of more currency gains in the near future. During the first quarter of 2008, the annualised monthly pace of the renminbi's appreciation against the US dollar averaged 15-20 per cent-the fastest pace since the exchange rate policy reform in July 2005 (Figure 2.11). In April, this pace decelerated sharply to about zero, before picking up again to about 10 per cent in early June.

\section{Concluding remarks}

Like most other economies in the world, China currently faces the extraordinary challenge of slowing growth and rising inflation. Some continuing changes, especially the slow-down of the US economy, elevated oil prices and the normalisation of domestic costs, are likely to reinforce this challenge in the coming months. The probability of stagflation, however, remains extremely remote. Real GDP growth will likely moderate slightly; however, barring major surprises, China should be able to comfortably maintain growth of about 10 per cent in the next five years. The earthquake in early May in Sichuan was a human tragedy, but its direct economic cost should be limited.

Inflation rates, however, could move up, although the food-driven CPI should moderate further in the coming months. The low-inflation phase of the past 10 years, supported by relocation of factories and labour and associated productivity gain, is probably over. The anticipated broad-based increases in costs of factors including labour, land, capital, energy and the environment imply that the economy should face inflationary pressures that are stronger than ever. More and more policymakers will also adopt the idea of the need to tolerate high inflation. Given that China is still a developing country and a transitional economy, it is reasonable to expect it to maintain 5 per cent inflation. This could open the door to major inflation problems, as the central bank is always behind the curve.

Tight monetary policy is likely to continue, as long as inflation remains a key risk. The central bank will, however, probably continue to focus on liquidity management. It stopped hiking its policy rates for fear of attracting more capital inflows. Currency appreciation will probably maintain an annual pace of 5-10 per cent in the coming year or two, despite recent dramatic fluctuations in 
market expectations. At the end of the day, policymakers will have to strike a balance between the need to rebalance the economy and the need for smooth structural adjustments. Job losses remain the top concern for the government. For the same reason, the probability of one-off revaluation or devaluation looks extremely low. If, however, the global financial risks recede quickly in the coming months, the reform of the exchange rate policy and liberalisation of the capital account could accelerate significantly.

Currently, the Chinese authorities employ a combination of tight monetary policy and neutral fiscal policy. While the purpose of tight monetary policy is to control inflation, the intention of neutral fiscal policy is to prevent downside risks to the economy. Fiscal policies could turn more expansionary in the second half of 2008 or in 2009. First, the government will probably need to spend at least RMB250 billion—or 1 per cent of GDP_every year in the next three years for post-earthquake reconstruction. Second, the government needs to play a more active role in facilitating structural adjustment, including helping technological upgrading and re-employment. Finally, active fiscal spending could boost domestic demand, lower the external account surplus, reduce capital inflow and ease inflationary pressure.

There is a misunderstanding among many economists and policymakers that China needs to reduce investment. One important reason for this is the risk of over capacity. While overcapacity risks existed in certain industries at certain times, there is no evidence of an economy-wide overcapacity problem. There is still huge investment potential in areas of urban development, the resources sector and environmental protection. In fact, a large current account surplus means China needs to expand its domestic demand in order to rebalance the economy. China needs less but better quality investment.

Finally, 2008 could be the first year since 2001 in which the Chinese economy sees a major downturn in growth. This could point to significant increases in financial risks. The stock index has already declined by 50 per cent from its peak in late 2007. Housing prices are also becoming less stable. The banking sector has already experienced major reform steps during the past six years, but the new institutions have not had any stress tests. A 1998 East Asian-type financial crisis is unlikely; however, any significant increases in financial risks could still lead to losses of large amounts of financial assets. 